
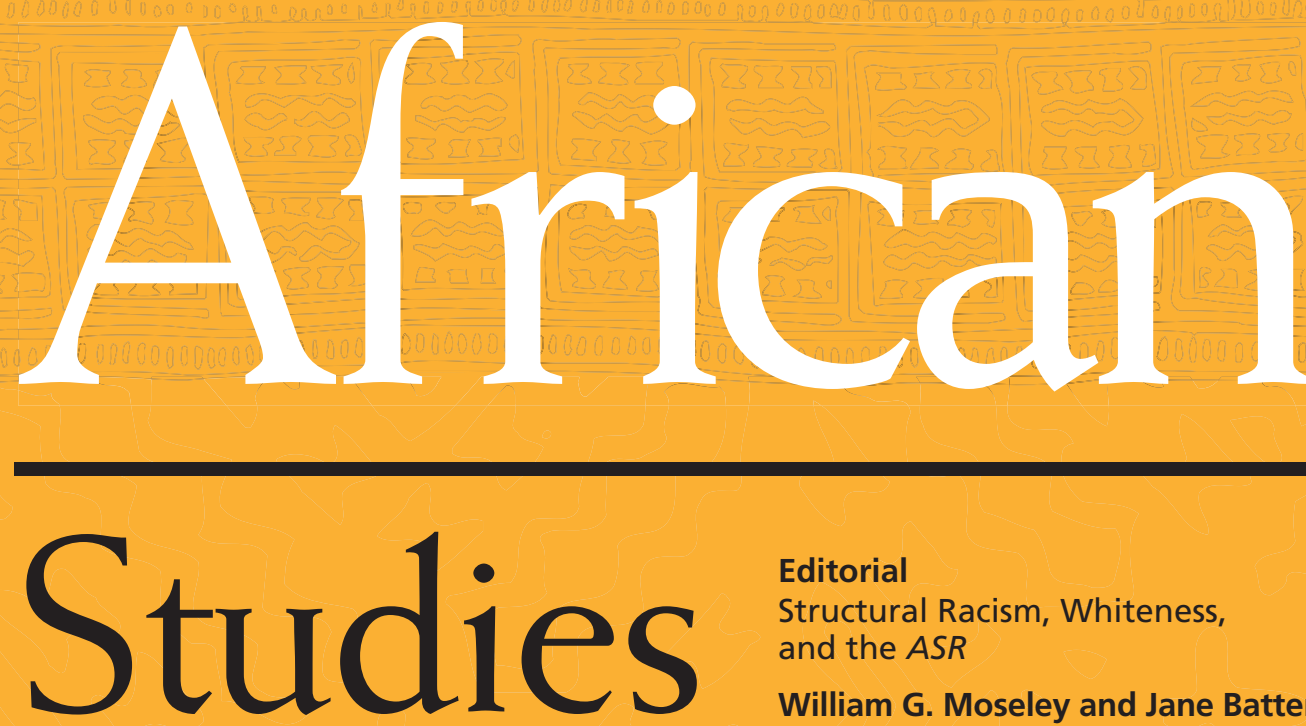

\title{
Editorial
}

Structural Racism, Whiteness, and the ASR

William G. Moseley and Jane Battersby Commentary: African Food Systems and COVID-19

\section{Coleman Donaldson}

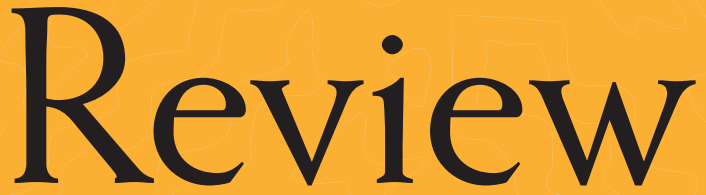

Islam and Sulemaana Kantè's N'ko

M. Victoria Gorham

Museums and Nation-Building in

Tanzania and Kenya

\section{Lydia Boyd}

Uganda's Christian Orphan Choirs

\section{Mario Krämer}

PUBLISHED FOR THE AFRICAN STUDIES ASSOCIATION

Political Dynamics in KwaZulu-Natal

FORUM: AFRICAN REFUGEE HISTORY

Christian A. Williams

Editor's Introduction

\section{Bonny Ibhawoh}

Humanitarianism in the Nigerian Civil War

Christian A. Williams

The Refugee Biography of Mawazo

Nakadhilu

Duduzile S. Ndlovu

Imagining Zimbabwe as Home

\section{Maarten Bedert}

Landlord-Stranger Reciprocity in

Contemporary Liberia

Katherine Luongo

The Supernatural in Global African Refugee Mobilities 


\title{
African Studies Review
}

\author{
The Journal of the African Studies Association
}

The African Studies Review (ASR) is the flagship scholarly journal of the African Studies Association (USA). The ASR publishes the highest quality African studies scholarship in all academic disciplines. The ASR's rigorous interdisciplinary peer review seeks to contribute to the development of scholarly conversations of interest to the diverse audience of the Association's membership and to the growth of African studies in North America, on the African continent, and in a global comparative context. (C) African Studies Association, 2020. All rights reserved.

\section{Subscription information}

African Studies Review (ISSN 0002-0206) is published quarterly in March, June, September, and December by Cambridge University Press, One Liberty Plaza, New York, NY 10006. Annual subscription rates for Volume 63, 2020: Institutions, print and online: US $\$ 630.00$ in the U.S.A., Canada, and Mexico; UK $\$ 393.00$ elsewhere. Institutions, online only: US $\$ 517.00$ in the U.S.A., Canada, and Mexico; UK $f 328.00$ elsewhere. Single part rate: US $\$ 181.00$ in the U.S.A., Canada, and Mexico; UK $f 147.00$ elsewhere.

Prices include postage.

For customers in North America

Email: subscriptions_newyork@cambridge.org; Phone (800) 872 7423, option 4

For customers outside of North America

Email: journals@cambridge.org; Phone +44 (0)1223 32 6070; Fax +44 (0)1223 325150

Manuscript submissions

http://mc.manuscriptcentral.com/africanstudiesreview

\section{Advertising}

To advertise in the journal please email USAdSales@cambridge.org or telephone +1 (212) 3375053 in the USA, Canada, or Mexico; email ad_sales@cambridge.org or telephone +44 (1223) 325083 in the rest of the world.

\begin{abstract}
ing and indexing
Articles published in African Studies Review are indexed by CrossRef, EBSCO, Google Scholar, H.W. Wilson Humanities Abstracts ${ }^{\mathrm{TM}}$; IBSS: International Bibliography of the Social Sciences; Microsoft Academic Search; MLA International Bibliography; Scopus ${ }^{\mathrm{TM}}$; Social Science Electronic Publishing; the English Historical Review; Thomson-Reuters Social Science Citation Index/Arts and Humanities Citation Index/Journal Citation Report
\end{abstract}

Permissions: All rights reserved. No part of this publication may be reproduced, in any form or by any means, electronic, photocopying, or otherwise, without permission in writing from Cambridge University Press. Policies, request forms and contacts are available at: cambridge.org/about-us/rights-permissions

Permission to copy (for users in the USA) is available from Copyright Clearance Center http://www.copyright.com, email info@copyright.com.

Reprints of individual articles may be ordered. For information on reprints, please contact Cambridge University Press.

Postmaster: Send address changes in the USA, Canada, and Mexico to: African Studies Review, Cambridge University Press, Journals Fulfillment Department, One Liberty Plaza, New York, NY 10006. Send address changes elsewhere to African Studies Review, Cambridge University Press, Journals Fulfillment Department, University Printing House, Shaftesbury Road, Cambridge CB2 8BS, UK.

Cover: Cover design by Craig Malone. Cover image based on Bambara discharge-dyed mud cloth, from African Designs by Rebecca Jewell. A British Museum Pattern Book. London: British Museum Press, 1994, Plate 55. Used by permission. 


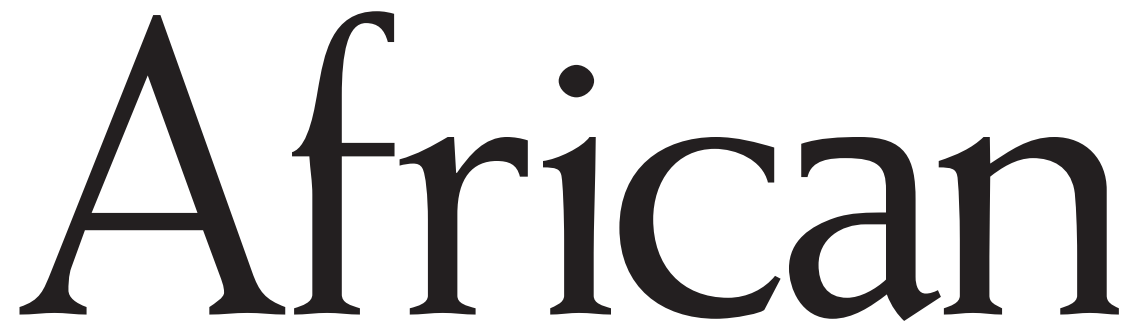

Studies Review

VOLUME 63, NUMBER 3

SEPTEMBER 2020

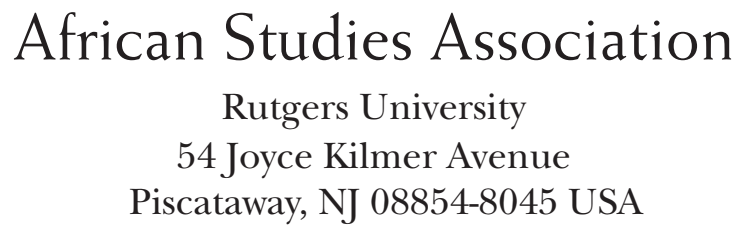




\section{African Studies Association The Journal of the African Studies Association}

\author{
African Studies Association \\ Rutgers University - Livingston Campus \\ 54 Joyce Kilmer Avenue \\ Piscataway, NJ 08854 USA \\ VOICE: 848-999-4455 \\ E-MAIL \\ secretariat@africanstudies.org \\ WEB SITE: \\ http://cambridge.org/asr
}

\section{Editor-in-Chief}

Benjamin N. Lawrance

University of Arizona, USA

\section{Editors}

Peter Alegi

Micbigan State University, USA

Annie Bunting

York University, Canada

Ayo Coly

Dartmoutb College, USA

Akosua Darkwah

University of Ghana, Ghana

Claudia Gastrow

University of Jobannesburg, South Africa

Cajetan Iheka

Yale University, USA

Dominika Koter

Colgate University, USA

Benjamin Talton

Temple University, USA

Cheikh Thiam

School for International Training, Senegal

\section{Book Review Editors}

Dawne Curry

University of Nebraska-Lincoln, USA
Olabode Ibironke

Rutgers University, USA

Tamba M'bayo

West Virginia University, USA

Aïssatou Mbodj-Pouye

Centre National de la Recherche Scientifique, France

Paul Ocobock

University of Notre Dame, USA

Ana Lúcia Sá

ISCTE-Instituto Universitário de Lisboa, Portugal

António Tomás

University of Jobannesburg, South Africa

John Wakota

University of Dar es Salaam, Tanzania

\section{Film Review Editors}

Kenneth Harrow

Michigan State University, USA

Rachel Gabara

University of Georgia, USA

Alessandro Jedlowski

FNRS, Free University of Brussels, Belgium

Obododimma Oha

University of Ibadan, Nigeria

Boukary Sawadogo

City College of New York/CUNY, USA

\section{Managing Editor}

Kathryn Salucka

African Studies Association, USA

\section{Editorial Review Board}

Moradewun Adejunmobi

University of California, Davis, USA

Akosua Adomako Ampofo

University of Ghana, Ghana

Ana Lucia Araujo

Howard University, USA

Books for review should be sent to Kathryn Salucka, Managing Editor, African Studies Association, 1270 Caroline St., Suite D120-358, Atlanta, GA 30307. The African Studies Review does not accept unsolicited book or film reviews. 
Leonardo Arriola

University of California, Berkeley, USA

Maxim Bolt

University of Oxford, UK

Catherine Boone

London School of Economics, UK

Therese De Raedt

University of Utab, USA

Didier Gondola

Indiana University/Purdue University

Indianapolis, USA

Mwangi wa Gĩthĩnji

University of Massacbusetts, Amberst, USA

Bruce Hall

University of California, Berkeley, USA

John R. Heilbrunn

Colorado School of Mines, USA

Barbara G. Hoffman

Cleveland State University, USA

Rosemary Jolly

Pennsylvania State University, USA

Kwasi Konadu

Colgate University, USA

Patricia Makepe

University of Botswana, Botswana

Judith Miller

New York University, USA

William Moseley

Macalester College, USA

Tinashe Mushakavanhu

Rbodes University, South Africa

Garth A. Myers

Trinity Collede, USA

Ghirmai Negash

Obio University, USA

Fallou Ngom

Boston University, USA

Akinwumi Ogundiran

University of North Carolina at

Charlotte, USA

Chika Okeke-Agulu

Princeton University, USA

Anne Pitcher

University of Michigan, USA

Katrien Pype

KU Leuven, Belgium

Solofo Randrianja

University of Toamasina, Madagascar
Sean Redding

Amberst College, USA

Tricia Redeker Hepner

University of Tennessee, USA

Benedetta Rossi

University of Birmingham, UK

Rüdiger Seesemann

Universität Bayreuth, Germany

Alice Nicole Sindzingre

School of Oriental and

African Studies, UK

Omar Sougou

Université Gaston Berger, Senegal

Rhiannon Stephens

Columbia University, USA

Judith Van Allen

Cornell University, USA

Awet Weldemichael

Queens University, Canada

\section{Editors Emeriti}

Rowland Abiodun

Amberst College, USA

R. Hunt Davis Jr.

University of Florida, USA

Mark DeLancey

University of South Carolina, USA

Mamadou Diouf

Columbia University, USA

Ralph Faulkingham

University of Massacbusetts, USA

Elliot Fratkin

Smith College, USA

Mitzi Goheen

Amberst College, USA

Jane Guyer

Jobns Hopkins University, USA

John P. Henderson

Michigan State University, USA

Tabitha Kanogo

University of California, Berkeley, USA

John Lemly

Mt. Holyoke College, USA

Alan K. Smith

Syracuse University, USA

Carol B. Thompson

Northern Arizona University, USA

Richard Waller

Bucknell University, USA 


\section{African Studies Review}

VOLUME 63， NUMBER 3，SEPTEMBER 2020

443 Editors' Introduction

African Studies Review Editorial Collective and

Benjamin N. Lawrance

\section{COMMENTARY}

449 The Vulnerability and Resilience of African Food Systems, Food Security, and Nutrition in the Context of the COVID-19 Pandemic William G. Moseley and Jane Battersby

\section{ARTICLES}

462 The Role of Islam, Ajami Writings, and Educational Reform in Sulemaana Kantè's N'ko

Coleman Donaldson

487 Displaying the Nation: Museums and Nation-Building in Tanzania and Kenya

M. Victoria Gorham

518 Circuits of Compassion: The Affective Labor of Uganda's Christian Orphan Choirs

Lydia Boyd

540 Violence, Autochthony, and Identity Politics in KwaZulu-Natal (South Africa): A Processual Perspective on Local Political Dynamics

Mario Krämer

\section{FORUM: AFRICAN REFUGEE HISTORY}

560 Editor's Introduction

Christian A. Williams

Published for the African Studies Association by Cambridge University Press 
568 Refugees, Evacuees, and Repatriates: Biafran Children, UNHCR, and the Politics of International Humanitarianism in the Nigerian Civil War

Bonny lbhawoh

593 SWAPO's Struggle Children and Exile Home-Making: the Refugee Biography of Mawazo Nakadhilu

Christian A. Williams

616 Imagining Zimbabwe as Home: Ethnicity, Violence and Migration

Duduzile S. Ndlovu

640 Refugees, Identity, and the Limits to Inclusion: Revisiting Landlord-Stranger Reciprocity Relations in Contemporary Liberia Maarten Bedert

660 "The Problem of Witchcraft": Violence and the Supernatural in Global African Refugee Mobilities

Katherine Luongo

\section{BOOK REVIEWS (ONLINE)}

\section{AFRICA - GENERAL}

E1 Mariana P. Candido and Adam Jones, eds. African Women in the Atlantic World: Property, Vulnerability \& Mobility, 1660-1880. Ana Lucia Araujo

E4 Frieda Ekotto and Kenneth W. Harrow, eds. Rethinking African Cultural Production. Bhekizizwe Peterson

E7 Peter Elliott. Constance: One Road to Take. The Life and Photography of Constance Stuart Larrabee (1914-2000). Rick Halpern

E10 Robert Launay, ed. Islamic Education in Africa: Writing Boards and Blackboards.

Marta Scaglioni

E13 Mimmi Söderberg Kovacs and Jesper Bjarnesen, eds. Violence in African Elections: Between Democracy and Big Man Politics. Claudia Generoso de Almeida 


\section{EAST AFRICA}

E16 Ned Bertz. Diaspora and Nation in the Indian Ocean:

Transnational Histories of Race and Urban Space in Tanzania.

Gregory H. Maddox

E18 Laura Fair. Reel Pleasures: Cinema Audiences and Entrepreneurs in Twentieth-Century Tanzania.

Laura Edmondson

\section{CENTRAL AFRICA}

E21 Susanne Jaspars. Food Aid in Sudan: a history of power, politics and profit.

Steve Howard

E23 Muḥammad ibn 'Umar al-Tūnisī. In Darfur: An Account of the Sultanate and Its People.

Shamil Jeppie

\section{SOUTHERN AFRICA}

E26 Zachary Kagan Guthrie. Bound for Work: Labor, Mobility, and Colonial Rule in Central Mozambique, 1940-1965.

Sandra Sousa

E28 David Morton. Age of Concrete: Housing and the Shape of Aspiration in the Capital of Mozambique.

António Tomás

E30 Morgan Ndlovu. Performing Indigeneity: Spectacles of Culture and Identity in Coloniality.

Robert Maseko

E32 Elizabeth Thornberry. Colonizing Consent: Rape and Governance in South Africa's Eastern Cape.

Chet Fransch

\section{WEST AFRICA}

E35 Marcus Filippello. The Nature of the Path: Reading a West African Road.

Nathan Riley Carpenter

E38 Laura S. Grillo. An Intimate Rebuke: Female Genital Power in Ritual and Politics in West Africa.

Jill E. Kelly 
E41 Kathleen Keller. Colonial Suspects: Suspicion, Imperial Rule and Colonial Society in Interwar French West Africa.

Fabienne Chamelot

E44 Adam Mayer. Naija Marxisms: Revolutionary Thought in Nigeria. Emmanuel Nwafor Mordi

E47 Terri Ochiagha. A Short History of Chinua Achebe's Things Fall Apart.

Ignatius Chukwumah

E50 Steven Pierce. Moral Economies of Corruption: State Formation and Political Culture in Nigeria.

Azeez Olaniyan

E53 David A. Schwartz, Julienne Ngoundoung Anoko, and Sharon Abramowitz, eds. Pregnant in the Time of Ebola: Women and Their Children in the 2013-2015 West African Epidemic.

Catherine Bolten

\section{FILM REVIEWS (ONLINE)}

\section{FEATURE FILMS}

E56 Mati Diop, dir. A Thousand Suns.

Kenneth W. Harrow

E59 Mati Diop, dir. Atlantique.

Benjamin N. Lawrance

E62 John Trengove, dir. The Wound.

Elizabeth Thornberry 